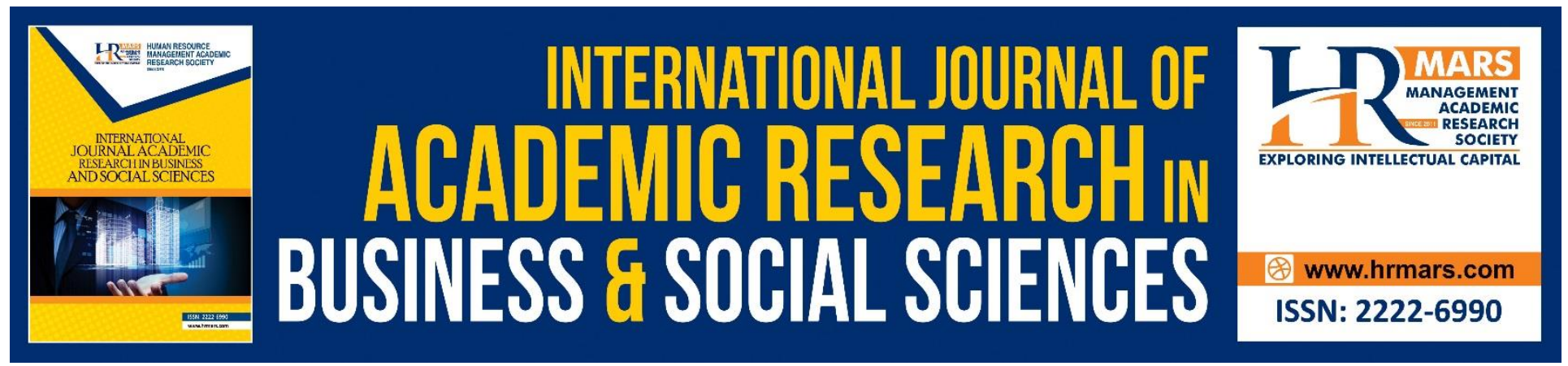

\title{
Accentuating Customer Engagement, Visual Presentation and Copywriting for Effective Social Media Marketing: A Case Study
}

Nooraini Mohamad Sheriff, Aisya Syahira Zulkifli, Wan NurShahira Wan Othman

To Link this Article: http://dx.doi.org/10.6007/IJARBSS/v8-i12/5263

DOI: $10.6007 /$ IJARBSS/v8-i12/5263

Received: 08 Nov 2018, Revised: 21 Dec 2018, Accepted: 09 Jan 2019

Published Online: 11 Jan 2019

In-Text Citation: (Sheriff, Zulkifli, \& Othman, 2018)

To Cite this Article: Sheriff, N. M., Zulkifli, A. S., \& Othman, W. N. W. (2018). Accentuating Customer Engagement, Visual Presentation and Copywriting for Effective Social Media Marketing: A Case Study. International Journal of Academic Research in Business and Social Sciences, 8(12), 1619-1628.

Copyright: (C) 2018 The Author(s)

Published by Human Resource Management Academic Research Society (www.hrmars.com)

This article is published under the Creative Commons Attribution (CC BY 4.0) license. Anyone may reproduce, distribute, translate and create derivative works of this article (for both commercial and non-commercial purposes), subject to full attribution to the original publication and authors. The full terms of this license may be seen

at: http://creativecommons.org/licences/by/4.0/legalcode

Vol. 8, No. 12, 2018, Pg. 1619 - 1628

http://hrmars.com/index.php/pages/detail/IJARBSS

JOURNAL HOMEPAGE

Full Terms \& Conditions of access and use can be found at http://hrmars.com/index.php/pages/detail/publication-ethics 


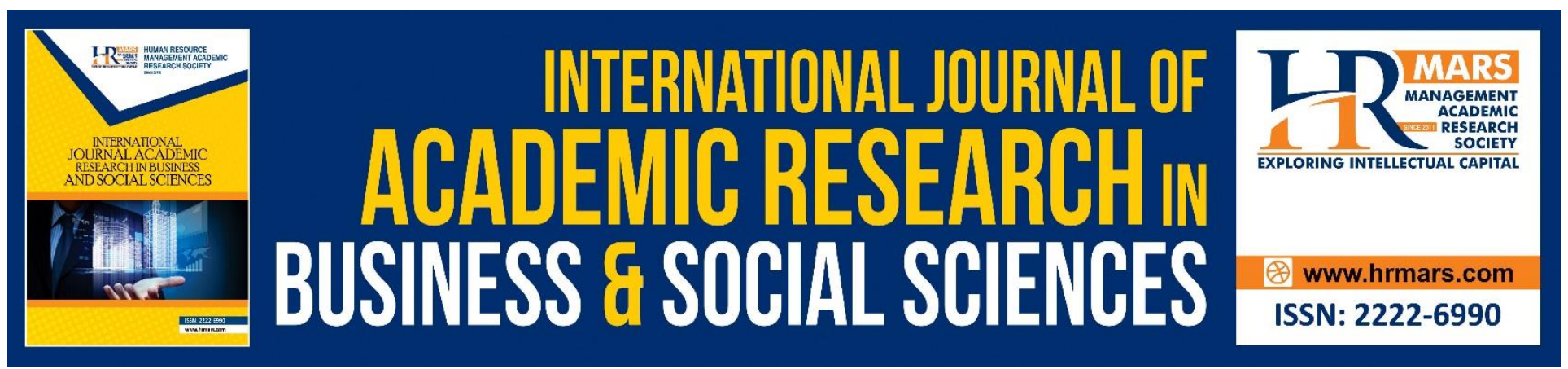

\title{
Accentuating Customer Engagement, Visual Presentation and Copywriting for Effective Social Media Marketing: A Case Study
}

\author{
Nooraini Mohamad Sheriff, Aisya Syahira Zulkifli, Wan NurShahira Wan \\ Othman \\ Arshad Ayub Graduate Business School, Faculty of Business Management \\ UiTM Shah Alam, Selangor, Malaysia
}

\begin{abstract}
This study examined features embedded in social media namely customer engagement, attractive visual presentation and copywriting that are capable of driving online purchase for apparels. As the Malaysian fashion retail industry actively adopts social media marketing there is a need to ascertain the extent to which the aforesaid features could be more effectively designed to draw the attention of online customers to a firm or brand and induce purchase. A census of 170 online customers from an apparel retailer was taken for this study. Online questionnaire link in Google document was emailed to the company's sales team who in turn blasted the online questionnaire via email to all of their online customers in their data base. The study uncovered that customer engagement (.004) and visual presentation (.013) were significant at 0.05 level of significance. The standardized beta coefficients indicated that customer engagement had the strongest influence (.350) on online purchase for apparels, followed by visual presentation (.330). Hence suggesting that online firms using social media must ensure they engage their online customers through discussions, reviews, contest and comments to understand them better and ultimately stimulate purchase. Social media too needs an outstanding visual presentation to reduce the perceived risk among online customers and facilitate their purchase of apparels.
\end{abstract}

Keywords: Social Media, Customer Engagement, Visual Presentation, Copywriting, Online Purchase

\section{INTRODUCTION}

The Malaysian apparel retail industry had recorded total revenue of RM1.8 billion in 2013, representing a compound annual growth rate of $14.4 \%$ between 2009 and 2013 and is forecasted to further grow in the upcoming years(Newstex Trade \& Industry Blogs,2014). In 2016, online retailing for fashion wear garnered RM135.2 million in revenue and is expected to show an annual growth rate of $14.8 \%$ with a market volume totaling RM235 million by 2020 (Statista, 2016). Malaysian consumers are keen to engage in internet retailing because of the convenience of being able make price comparison of products and enjoy special deals that are commonly offered online. Manjur (2016) 
postulated that Malaysian consumers are portraying a continually increasing pleasure for quicker service at their choice of location and over $60 \%$ of consumers in Malaysia are willing to pay for sameday delivery of online orders. The fashion retail industry has recognized the emergence of opportunities to grow their business into internet retailing or often termed as online shopping. Nielsen (2014) reiterated that apparel and fashion ranked as the second most bought product category after electronic products. With technological advancement businesses have began to incorporate the use of social media marketing (SMM) to heighten revenue and company's growth. According to Saravanakumar\&Sugantha (2012), SMM being internet-based marketing utilizes channels of social media to interact and attract prospective customers using captions, posts, pictures or videos. Additionally SMM is becoming increasingly important in facilitating consumers' purchase decision mainly because they amplify word-of-mouth which is often construed as a trusted source of information (Karami\&Naghibi, 2014).SMM techniques too have contributed to increase brand awareness, sales and improve customer service (Cox \&Birchman, 2012). In short, social media has assisted to bring potential customer in and it is a great platform for retail business promotion and marketing. Thus companies should take advantage of the increasing trend of customers relying on social media for their purchases (Yogesh \&Yesha, 2014).

Consumer's engage in a purchase process to satisfy two main needs, namely solve a problem and to increase pleasure (Ahmed, 2015) and the purchase process is concerned with how consumer's made their buying decision (Schiff man, Bednall, O'Cass, Paladino, \&Kanuk, 2005). The internet has created an online environment which has affected all stages of consumer decision making process from searching for alternatives, gathering required information, evaluation of different retailers, providing personal information and payment process. Specifically the internet has altered consumer's behavior by offering conveniences to information search, alternative evaluation and decision to purchase (Karami\&Naghibi, 2014).

Schiffman et al. (2005), postulated that consumers tend to make two types of purchase which are trial purchase and repeat purchase. Trial purchase is when consumer buys the product for the first time, in a small quantity to evaluate the product. If the product is good and satisfying repeat purchase is likely to occur. A purchase decision process encompasses consumer's decision on whether to buy, when to buy, what to buy, where to buy and how to pay (Blackwell, Miniard, \& Engel, (2006). Karami\&Naghibi (2014) advocated online purchase decision making process to be characterized as ad-hoc, unstructured and highly dynamic since consumers do not really follow a predefined set of procedures. At the end of evaluation stage consumers would have identified the best product or brand to be purchased. However, a key setback of online purchase is the inability to physically examine a product especially tactile product attributes. Clothing's have the highest return rate from online purchase as compared to those bought from a physical store. Nonetheless with technological advancement, online channels has evolved to compensate for the lack of physical contact for garment through the use of product virtualization technologies, such as 3-D rotation views and Virtual Try-on technologies (Karami\&Naghibi, 2014). The use of online channels particularly social media must be accompanied by salient features such as customer engagement, attractive visual presentation and copywriting to optimize their impact on customers making online purchases for apparels. 
Customer engagement is customers expression of a brand or firm, beyond purchase, stemming from motivational drivers such as online posts, comments and participation in online games or activities (Yamamoto, H., 2015). Social media allows greater exposure and engagement with customers and promotes brand existence(Doyle, J., 2011).Connecting with customers through social media allows a brand to connect with customers and monetize on it through awareness, loyalty and engagement (Akahoshi, 2012). Engagement in social media can manifest in the form of "like" a brand and its products or by being a member of a brand's social media page (Anastasia, 2012). Customers can become fans of these brand fan pages and subsequently indicate that they like the brand post or comment on it. This "like" and "comment" on brand posts reflects brand post popularity (De Vries, Gensler, \&Leeflang, (2012). Engagement can be as simple as posting comments, giving votes or as complex as recommending content to other user on the basis of their preferences, interests and lifestyle (Bashar, Ahmad, \&Wasiq,2012).Product review is an indicator that a business has engaged with their customers. A review is good if it is positive and is of high quality if accompanied by logical, persuasive and factual reasoning about the product. Reitz (2012) opines thatengagement is the most important online process companies need to deliver to build their competitive advantage which may pave the way for customer loyalty.According to Redsicker (2014), the hallmark of SMM is to establish emotional connections with customers through the creation of positive customer experiences, exceptional service and engaging conversations. As such brands should be active through social media's to display their existence and encourage higher traffic. Technological advancement has encouraged customers to interact with brands, that ultimately build brand awareness, increase involvement and engagement with customers that eventually stimulates purchase.Online customer engagement too can help build relationship between a brand and customer which inturn could positively impact brand loyalty, brand evangelism, brand identification and affinity, brand learning, and sales (Mohr, 2013). Retailers'utilize the social networking sites to develop traffic to their physical locations and build customer engagement by encouraging product reviews and discussions (Pentina \& Koh, 2012). Customers too yearn for a platform to channel their requests, concerns, loyalty rewards, special offers, updates and additional information on products (Carter,2014). Thus, engaging the use of social media is a good platform for retailers to promote their product and build customer's trust which in turn may stimulate loyalty towards their brand (Wallsbeck, \& Johansson, 2014).

Visual presentation on the other hand is used to communicate and share information visually. Forms of visual presentation includes physical objects, photographs, maps, slides, overheads and computer generated presentations which conveys what words alone cannot, explain abstract concepts, aid retention of information and maintain audience interest (Stoner, 2009). Image is often the first thing that catches customer's attention since it can be easily interpreted than words and positively influences consumer's purchase decision. Customers tend to display stronger interest to good looking advertisements and content (Wallsbeck, \& Johansson, 2014). To this effect visual presentation of products in social media serves as an effective direct communication with a firm's target market to potentially stimulate purchase intention (Lindahl,\&Öhlund, 2013).According to Wild (2016) creating a strong and impactful visual content would enable the visual to be catchy so that viewers would be attracted to see, enjoy and want to share them. Equally crucial is the selection of 
the best content type namely info graphics, images and videos. Wild (2016) too reported that info graphics are $30 \%$ more likely to be read than pure text-based content. In creating a good visual content, an attractive and effective design is critical. In addition typography, illustrations, simplicity and accuracy too needs equal attention. Quality of visual content is important as it can help draw customer's attention (Ladd, 2010). It is imperative that every brand have their own visual identity to showcase the product to customers (Augustini, 2014). Above all it is vital to ensure the accuracy of the design to avoid disseminating misleading information to customers.

Consequently, content writing is concerned with the creation of content that markets well and copywriting is the secret ingredients to good content writing. The aim of copywriting is to sell the real worth of the brand, products and services because it is attractive and can capture audience's attention. To date web content has evolved around copywriting to connect with potential customers and sell effectively by revealing the greatness of the brand (Smith, 2014). Copywriting may be present in advertisements, websites, catalogues, sales letter and brochures which can be categorized as offline and online copywriting. Online copywriting involves business owners dealing directly with vocal, active and connected audience in the sales and marketing(Eisenberg, Eisenberg, \& Davis, 2006). Nevertheless prior to using copywriting businesses need to identify their potential target audience to whom their product would be sold to ensure that the copywriting is most effective (Olah,2012). As such copywriting must be capable of getting attention, communicate, persuade and convince consumers' to buy a product(Bly, 2005). Olah (2012) concurs that good copywriting must have an attention-getting headline where readers' attention is grabbed to lure them into reading what is written. In fact, headline may perform four different tasks which are to get attention, select audience, deliver complete message and draw readers to a body copy. Thus, headline should include a complete message that is concise to draw readers' attention to the body copy by arousing reader's curiosity (Bly,2005).

Following the established frame of thought the conceptual model depicted in Figure 1 established the influence of customer engagement, visual presentation and copywriting of customer's online purchase for apparels.

Figure 1: Conceptual Diagram

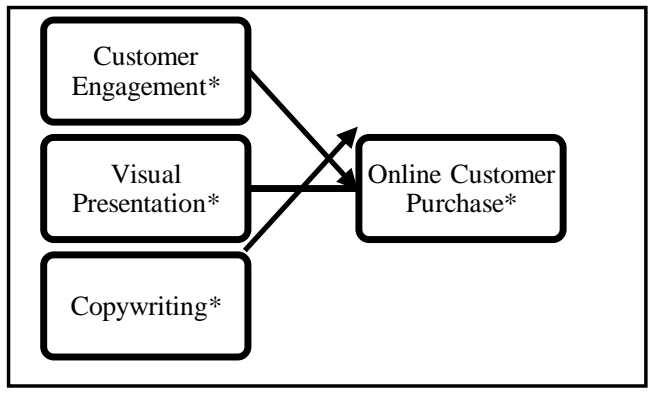

*Adapted from: Anastasia, M. (2012), Wallsbeck \&

Johansson (2014), Bly (2005) and Beese (2011) 


\section{METHODOLOGY}

Scaling and Data Collection: A six point Likert scale ranging from strongly agree or strongly disagree was utilized. Questionnaire for the study was transformed electronically by using Google Document as the online survey method was used for data collection. A pre-test of the questionnaire was done among apparel shoppers who were familiar with social media and online purchase. The target population were all online customers in a selected company's database between $19^{\text {th }}-23$ December 2016. There were a total of 170 online customers over the period for data collection, hence a census was taken. Distribution of online questionnaires was assisted where the online questionnaire link in Google document was emailed to the company's sales team who in turn blasted the online questionnaire via email to all of their online customers in their data base. Total questionnaires received and used for analysis was 128.

The Cronbach's Alpha values for variables in the study are online customer purchase (.881), customer engagement (.927), visual presentation (.944) with copywriting attaining .947. Thus implying all variables had good internal consistency.

Sample characteristics: Demographically $98 \%$ of the respondents were female with $48 \%$ in the 30 to 35 age group. A majority (74\%) were working women who lived in Selangor, WP Kuala Lumpur and WP Putrajaya (38\%) with monthly income of more than RM 4,000 per month (33\%). Most of the respondents engaged in online shopping for apparels once or more in a month (55\%) and prefer making online purchases through social media and company's website (80\%). Reason being most of them are working women and have limited time to shop offline at the apparels boutique. Instagram was preferred by a majority $(66 \%)$ to initiate their purchase.

\section{RESULTS and DISCUSSION}

Table 1:

Overall Mean, Standard Deviation and Variance.

\begin{tabular}{|l|c|c|c|}
\hline Variable & $\begin{array}{c}\text { Overall } \\
\text { Mean }\end{array}$ & $\begin{array}{c}\text { Standard } \\
\text { Deviation }\end{array}$ & Variance \\
\hline Online Customer Purchase (DV) & 5.25 & .849 & .722 \\
\hline Customer Engagement (IV) & 5.21 & .814 & .674 \\
\hline Visual Presentation (IV & 5.30 & .802 & .653 \\
\hline Copywriting (IV) & 5.21 & .799 & .642 \\
\hline
\end{tabular}

Customers have agreed that visual presentation has influenced their online purchase decision for apparels, with the highest overall mean of 5.30. Visual presentation of apparels via social media is an effective way of directly communicating with target market (Lindahl, \&Öhlund,2013). As such companies have begun to take advantage of the increasing trend of customers relying on social media fortheir purchases (Yogesh, \&Yesha, 2014).Customer engagement obtained an overall mean of 5.21. Connecting with customers through social media allows a brand to connect with customers and monetize on it through awareness, loyalty and engagement (Akahoshi, 2012). Consequently 
INTERNATIONAL JOURNAL OF ACADEMIC RESEARCH IN BUSINESS AND SOCIAL SCIENCES Vol. 8, No. 12, Dec, 2018, E-ISSN: 2222-6990 @ 2018 HRMARS

copywriting garnered an overall mean of 5.21. Attractive copywriting is aimed at selling the real worth of a brand, products and services through gaining audience's attention (Smith,2014).

Analysis of variance (ANOVA) indicated that customer engagement, visual presentation, copywriting and online purchase for apparels were significant at .000. The adjusted $R$ square obtained was .538, indicating that almost $58 \%$ of the variance for online customer purchase of apparels was explained by customer engagement, visual presentation and copywriting. Among three predictors customer engagement (.004) and visual presentation (.013) were significant at 0.05 level of significance. The standardized beta coefficients indicated that customer engagement has strongest influence (.350) on online purchase for apparels, followed by visual presentation (.330). Mohr (2013) postulated that engagement between customer and company will positively lead to a purchasing behavior and eventual loyalty (Reitz, 2012). Customer engagement too is important to assist firms in understanding their customer's reaction to a particular product or brand. Petina\&Koh, (2012) and Carter, (2014) added that increasing participation and discussion made through online helped to increase the impact of products and brands that eventually trigger customer to purchase. In addition, visual presentation too had influenced online purchase for apparels. Wallsbeck\& Johnson (2014), Lindahl\&Ohlund (2013) and Wild, (2016) advocated that appealing visual display of products helps to increase customer's intention to purchase the product. In addition detailed and accurate visual information on screen such as the colors and design may assist to reduce the perceived risk and facilitate purchase decision making. To this end Stone, (2009) also concurred that detail verbal descriptions of a product are important to positively influence consumer purchase decision. As such, to date many internet retailers have paid a lot of attention to visual product presentation as compared to verbal product presentation.

\section{Table 2}

Multiple Linear Regression Analysis: Customer Engagement, Visual Presentation, Copywriting and Online Purchase for Apparels

\begin{tabular}{|c|c|c|c|c|}
\hline \multirow[t]{2}{*}{ Independent Variables } & $\begin{array}{l}\text { Standardized } \\
\text { Coefficients }\end{array}$ & \multirow[t]{2}{*}{$\mathrm{t}$} & \multirow[t]{2}{*}{ Sig. } & \multirow{2}{*}{$\begin{array}{l}\text { Durbin- } \\
\text { Watson }\end{array}$} \\
\hline & Beta & & & \\
\hline & & 2.404 & .018 & \multirow[t]{4}{*}{2.219} \\
\hline Customer Engagement & .350 & 2.970 & .004 & \\
\hline Visual Presentation & .330 & 2.510 & .013 & \\
\hline Copywriting & .101 & .884 & .379 & \\
\hline R: .741 & \multirow{6}{*}{\multicolumn{4}{|c|}{$\begin{array}{l}F: 50.276 \\
\text { Sig.: } .000(p<0.05)\end{array}$}} \\
\hline R Square: .549 & & & & \\
\hline Adjusted R Square: .538 & & & & \\
\hline Std. Error of The & & & & \\
\hline Estimate: 2.37865 & & & & \\
\hline Durbin-Watson: 2.219 & & & & \\
\hline
\end{tabular}

$n=128$ 
INTERNATIONAL JOURNAL OF ACADEMIC RESEARCH IN BUSINESS AND SOCIAL SCIENCES

Vol. 8, No. 12, Dec, 2018, E-ISSN: $2222-6990$ C 2018 HRMARS

\section{CONCLUSION}

As online shopping has caught the attention of a sizable number of consumers' in the fashion retail industry, opportunities for growth are real. Apparel and fashion businesses should continue to incorporate the use of social media marketing (SMM) to heighten revenue and company's growth. In doing so aspects of customer engagement and visual presentation should be given innate attention to optimize the impact of social media in inducing online purchase. Consequently effective use of social media too can contribute to increase a firm's brand awareness, customer service which could eventually drive a firm's sale.

\section{REFERENCES}

1. Ahmed, M. (2015). Is Social Media the Biggest Influencer of Buying Decisions? Retrieved May 26, 2015, fromhttp://www.socialmediatoday.com/marketing/masroor/2015-05-28/social-mediabiggest-influencer-buying-decisions

2. Akahoshi, T. (2012). Transparency in the Fashion Industry: Social Media Use in Public Relations Strategies. California Polytechnic State University.

3. Anastasia, M. (2012). The influence of brand engagement in Social Network on the intention of consumers' to purchase a product regarding its brand equity. Erasmus Universities Rotterdam.

4. Augustini, M. (2014). Social Media and Content Marketing as a part of an effective Online Marketing strategy. Masaryk University.

5. Bashar, A., Ahmad, I., \& Wasiq, M. (2012). Effectiveness of Social Media as a Marketing Tool : an Empirical Study, 1(11), 88-99.

6. Beese, J. (2011). Social Networks Influence $74 \%$ of Consumers' Buying Decisions.https://sproutsocial.com/insights/social-networks-influence-buying-decisions/

7. Blackwell, R. D., Miniard, P. W., \& Engel, J. F. (2006). Consumer Behavior. 10th Edition Oklahoma: Thomson Higher Education.

8. Bly, R.W. (2005). The Copywriter's Handbook. Henry Holt and Company, LLC. Henry Holt and Company, LLC

9. Carter, J. (2014). Social Media Strategies in Small Businesses

10. Cox, S., \& Birchman, J. A. (2012). Social Media Marketing in a Small Business : A Case Study.

11. De Vries, L., Gensler, S., \&Leeflang, P. S. H. (2012). Popularity of Brand Posts on Brand Fan Pages: An Investigation of the Effects of Social Media Marketing. Journal of Interactive Marketing, 26(2), 83-91.

12. Doyle, J. (2011). An exploratory study of Social media marketing and traditional media in the Irish Fashion Industry. National College of Ireland.

13. Eisenberg, B., Eisenberg, J., \& Davis, L. T. (2006). Persuasive Online Copywriting: How to Take Your Words to the Bank. Future Now, Inc. New York: Future Now.

14. Karami, S., \&Naghibi, H. S. (2014). Social Media Marketing (SMM) Strategies for Small to Medium Enterprises (SMES). International Journal of Sales \& Marketing Management Research and Development (IJSMMRD), 4(4), 11-20.http://www.tjprc.org/viewarchives. php? year=2014\&jtype=2\&id=33\&details=archives 
INTERNATIONAL JOURNAL OF ACADEMIC RESEARCH IN BUSINESS AND SOCIAL SCIENCES

Vol. 8, No. 12, Dec, 2018, E-ISSN: 2222-6990 @ 2018 HRMARS

15. Ladd, A. D. (2010). Developing Effective Marketing Materials: Brochure Design Considerations. Agriculture, Center for Profitable Agriculture University of Tennessee Institute of Agriculture (December), 4-6.https://ag.tennessee.edu/cpa/Information\%20Sheets/cpa179.pdf

16. Lindahl, G., \&Öhlund, M. (2013). Personal Branding Through Imagification in Social Media: Identity Creation and Alteration through Images. Stockhol University.

17. Manjur, R. (2016). Online shopping in Malaysia expanding opening up doors for retailers.http://www.marketing-interactive.com/online-shopping-malaysia-expanding-openingdoors-retailers/

18. Mohr, I. (2013). The Impact of Social Media on the Fashion Industry. Journal of Applied Business and Economics, 15(2), 17-23.

19. Newstex Trade \& Industry Blogs. (2014). CompaniesandMarkets.com: Malaysia Apparel Retail Market: New market research published: Apparel Retail in Malaysia. Retrieved August 7, 2016,from

http://search.proquest.com.ezaccess.library.uitm.edu.my/abicomplete/printviewfile?accountid $=42518$

20. Nielsen Holding, N.V. (2014). Malaysians Rank among the World's Most Avid Online Shoppers.

21. Olah, G. (2012). A Guide to Copywriting to Promote your Business. Newbies HQ.

22. Pentina, I., \&Koh, A. C. (2012). Exploring social media marketing strategies in SMEs. Int. J. Internet Marketing and Advertising, 7(4), 292-310.

23. Redsicker, P. (2014). 5 Ways You Can Influence Consumer Purchasing Decisions: New Research.http://www.socialmediaexaminer.com/5-ways-brands-can-influence-consumerpurchasing-decisions/

24. Reitz, A. R. (2012). Online consumer engagement: Understanding the antecedents and outcomes. ProQuest Dissertations and Theses, 228.http://ezproxy.net.ucf.edu/login?url=http://search.proquest.com/docview/1038158077?ac countid=10003\%5Cnhttp://sfx.fcla.edu/ucf?url_ver=Z39.88

25. 2004\&rft_val_fmt=info:ofi/fmt:kev:mtx:dissertation\&genre=dissertations+\&+theses\&sid=ProQ:

ProQuest+Dissertations+\&+Th

26. Saravanakumar, M., \&SuganthaLakshmi, T. (2012). Social Media Marketing. Life Science Journal,9(4),4444-4451. http://www.lifesciencesite.com.

27. Schiffman, L., Bednall, D., O’Cass, A., Paladino, A., \&Kanuk, L. (2005). Consumer Behavior. (S. Wilson, C. Robson, L. Male, \& C. Leslie, Eds.) (3rd Edition). New South Wales: Pearson Education Australia.

28. Smith, A. (2014). The Unconventional Guide to Content Writing and Copywriting.https://www.searchenginejournal.com/unconventional-guide-content-writing-vscopywriting/114408/

29. Statista.

(2016).

E-commerce

Fashion.https://www.statista.com/outlook/244/122/fashion/malaysia\#

30. Stoner, G. M. (2009). Effectively Communicating with Visual Aids, 111.https://mattstoner.net/presentations/effective visuals.pdf

31. Wallsbeck, F. E., \& Johansson, U. (2014). Instagram Marketing - When Brands want to reach Generation $\mathrm{Y}$ with their Communication. Unpublished undergraduate thesis, Halmstad University. 
INTERNATIONAL JOURNAL OF ACADEMIC RESEARCH IN BUSINESS AND SOCIAL SCIENCES

Vol. 8, No. 12, Dec, 2018, E-ISSN: 2222-6990 @ 2018 HRMARS

32. Wild, F. (2016). Making an impact with visual content on social media.https://digitalcommunications.wp.st-andrews.ac.uk/2016/01/18/making-an-impactwith-visual-content-on-social-media/

33. Yamamoto, H. (2015). Enhancing engagement behavior using Shikake. Al and Society, 30(4), 519525. 